\title{
Digital Marketing for Acceleration of Indonesian Batik Export in the Global Pandemic of Covid-19
}

\author{
Agus Nursalim* \\ Department of Fine Arts Education Faculty of Art and Design Education \\ Universitas Pendidikan Indonesia \\ Bandung, Indonesia \\ *ans.sidiqp@gmail.com
}

\begin{abstract}
This study is aimed at determining the attitudes of Indonesian batik craftsmen and entrepreneurs in relation to economic stagnancy throughout Covid-19 pandemic. Indonesia has dominated batik market and has become its economic driver both at the regional and national level before Covid-19 pandemic. On Friday $(9 / 10 / 2020)$, the total infected people reached 36,4 milion around the world. Out of that number, 1,06 milion people died, while 25,4 milion people recovered. Thus, currently there are $\mathbf{9 , 9 4}$ milion active cases of Covid-19. This condition has made economies around the world collapsed including batik industries in Indonesia. This research used an ethnographic approach with observation, interviews and document analysis as research instruments to collect the data. The findings identify attitudes of craftsmen and entrepreneurs of Batik in responding to Covid-19 pandemic. As commonly known that the pandemic has caused economic crisis where many large-scale businesses have stagnated even stopped their activities. However, the Micro, Small and Medium Enterprises sector is more resilient in dealing with this. Thus, it needs a support from products and services of private and state-owned enterprises which have an important role in triggering economic growth in society especially for batik craftsmen.
\end{abstract}

Keywords-digital marketing, export acceleration, global covid19 pandemic, Indonesian batik entrepreneur

\section{INTRODUCTION}

One of the factors influencing development of Indonesian batik businesses is marketing strategy to promote batik products. This research examined digital marketing model as a strategy to expand and accelerate scope of consumers in regional, national, and international areas during Covid-19 pandemic situation. This is in line with Indonesian batik production which remains sluggish due to extreme decline of demand for batik products not only by local consumers but also by global consumers from various countries such as America, Japan and European countries. Generally, there are some points investigated in this study namely: how is the attitude of the batik craftsmen and entrepreneurs during Covid-19 pandemic, and what efforts did they make to maintain their business? This research is urgently done in order to revive Indonesian batik craftsmen and entrepreneurs through creating innovations in marketing of Small and Medium Enterprises products. Besides, there is a need to introduce accelerated strategies in Indonesian batik exports so that the economy of batik craftsmen and batik entrepreneurs can recover after great losses throughout Covid19 pandemic. In general, this condition of Batik industry has contributed to national economic growth because the products of small and medium-sized batik businesses play a role in growing the gross domestic product. The Ministry of Industry noted that the export value of the batik industry during the first semester of 2019 reached USD 17.99 million or equivalent to IDR 253,897 billion [1]. The main export destinations are Japan, United States, and Europe. The Minister of Industry said that batik industry has a great contribution in creating value, trade, amount of investment, impact on other industries, and speed of market penetration [2]. Batik business involves many parties including craftsmen, entrepreneurs, and investors to make policies either for internal, stake holders, or external parties.

- For crafters, the results of this study can provide insight to Indonesian batik artisans about product innovation in facing Covid-19 pandemic such as personal safety tools such as mask with new and fresh motives so that they can achieve maximum results. Hopefully, craftsmen will have positive abilities in developing new motives to face global market demands. In addition, it may increase the number of new batik motifs produced by craftsmen.

- For entrepreneurs, the results may increase sales value of innovative batik SME products because entrepreneurs have implemented digital marketing strategies to accelerate export of their batik products. The results of craftsmen's creative innovations can also be sold to local, regional, national and international consumers. The batik motifs as a result of creative response by Cirebon batik craftsmen can attract local and international buyers to meet global market demands.

- While for investors, the digital marketing acceleration strategy can increase marketing target of their batik products so that the capital that has been spent can 
return more quickly and they may get greater profits. From this fact, it will attract many investors who can support batik craftsmen and entrepreneurs to develop batik business. Thus, the existence of batik as an intangible cultural heritage will increasingly develop and be recognized by the international community.

\section{LITERATURE REVIEW}

Ani Handoko defines a marketing concept as a business philosophy mentioning that satisfying consumer needs by considering economic and social condition is important for the company's survival [2]. The marketing concept also states that the key to achieve organization goals is to make integrating marketing activities more effective than competitors in order to determine and satisfy the needs of the target market [3].

According to Kotler and Armstrong, marketing is a process by which companies create value for customers and build strong relationships with them to capture value from customers in return [4]. David further describes it as a process of defining, anticipating, creating, and fulfilling the needs and desires of consumers for products and services [5]. From this definition, it can be concluded that marketing is the process of creating, communicating, and delivering value which aims to understand the needs and desires of consumers for products and services as well as to establish relationships with customers and promote product sales.

\section{A. Conventional Marketing}

The term conventional marketing is also known as traditional marketing. Conventional marketing is commonly used by public until nowadays since it is still considered effective. Unfortunately, compared to rapid growth of technology, conventional marketing has not been fully able to compete with digital marketing. In this conventional marketing context, the seller must have capability to influence buyers and usually this method is used for people who are involved in the world of promotional marketing or business. Conventional marketing usually uses some tools such as advertising, brochures, public relations, trade shows / events, direct sales, and personal selling. They use these tools to attract and get consumers. Even, those still have a great impact on consumers. This era of internet-based information, conventional marketing is starting to get competitive with digital marketing. In fact, a fast access to product information, services, and easier transaction process makes many people turn to digital marketing and slowly leave conventional marketing.

However, the concept applied by digital marketing is quite similar with conventional marketing. The difference is only at faster and easier access to the products that digital marketing offers to costumers. Indeed, it improves customer satisfaction. Meanwhile, product types and concepts offered are the same as conventional marketing.

\section{B. Marketing Digital}

Digital Marketing uses internet and interactive technologies to connect dialogues between companies and consumers. They also argue that e-marketing is part of e-commerce [6]. The development of digital marketing through the web, mobile phones, and gaming devices, offers undeniable and influential advertising. So why don't marketers across Asia shift the use of budgets from traditional marketing such as TV, radio and print media towards new technology media and more interactive media? [7]. Digital marketing is a marketing activity including branding through various web-based media such as blogs, web sites, e-mail, or social networks. Nevertheless, digital marketing is not only talking about internet marketing [8].

From the description above, the most basic thing in marketing is customer satisfaction. Customer / consumer satisfaction is the main goal of marketers. Satisfaction can be reached both through conventional and digital marketing. Customer satisfaction is a level of person's feelings after comparing perceived results with his expectations. Satisfaction level is a function of difference between perceived results and expectations. Quality includes all elements needed to satisfy customer goals either from internal or external factors. The elements which support customer's satisfaction cover product item quality, service quality, performance, availability, durability, aesthetic, maintainability, logistics, supportability, customer service, training, delivery, billing, shipping, repairing, marketing, warranty, and life cycle cost [9].

John Deighton from Harvard Business School, identifies characteristics of digital media usage [10]:

- Customers initiate a contact;

- Customers are looking for information (there is an attraction);

- High intensity - the marketer will have 100 percent of the individual's attention when the customer looks at the website;

- The customers' needs can be addressed through dialogue

- The company may collect and store individual responses;

These two marketing strategies (conventional marketing and digital marketing) are the art of selling. Art is defined as an effort to achieve a desired result through intelligence. The art of selling does not only focus on conventional marketing or digital marketing but it covers skills of selling as a whole.

For example, the art of selling through digital marketing system requires interesting features that can attract consumers' interest to visit either using website, Facebook, Instagram, WhatsApp, or other media. It also includes providing attractable packaging, simple transaction process, fast shipping process and ease access to services which all of them is a part of providing good services to consumers. 


\section{RESEARCH METHODS}

This study used a descriptive research method with a qualitative approach. This approach was applied to examine the condition of a natural object. It means that the object naturally develops and the presence of the researcher does not affect the object at all. The data were collected through interview, art work (batik handicrafts), artifacts, and photo. The data in the form of information were then presented in the form of a narrative description in order to obtain objective, comprehensive and in-depth information related to attitudes of craftsmen and entrepreneurs in facing Covid-19 pandemic. In general, there are three kinds of research objectives, namely discovery, verification, and development. Discovery means that the obtained data from the study are completely novel that were previously unknown. Proof means that the data are used to prove doubts about certain information or knowledge. While, development means deepening and expanding existing knowledge. Sampling was carried out purposively on craftsmen in several cities namely Cirebon, Pekalongan, Sragen, and Surakarta. The results of qualitative research emphasize meaning of the data rather than making generalization. Another character of qualitative research is carried out in natural conditions, descriptive, and in the form of words or images. Thus, instead of emphasizing numbers, products, or outcomes, it emphasizes processes. Qualitative research analyzes data in an inductive manner and focuses on meaning [11].

In this study, ethnographic research design was used for several considerations. First, this study concentrates on in depth observation and interaction captured in the research subject [12]. Thus, data that describes characteristics of Cirebon batik craftsman community such as socio-cultural background, behavior, and views were identified through several research instruments including; interviews with craftsmen, entrepreneurs, and batik artists. Document analysis in this study covers analysis of batik works, pictures of batik activities, and marketing leaflets found in the batik business area.

Therefore, it is not surprising that research with this approach will take a relatively longer time to complete [13]. Mulder added that an ethnographer cannot conduct research without first doing a theoretical study related to the observed facts in the field. In connection with the research purpose, this study seeks to examine in depth the original batik motifs of Wadasan and Megamendung as two types of batik motifs in Cirebon palace. Apart from that, the researcher also aims to observe the behavior and culture of business transactions among craftsmen in Trusmi, Cirebon. Furthermore, the researcher examined creative responses made by Trusmi batik artisans in facing global market changes.

Besides that, ethnographic design was chosen to get a clear portray about phenomena in the field [14]. In addition, in line with Agroseno, the researcher wanted to look closely and deeply about the attitudes of entrepreneurs towards Covid-19 pandemic that underlines natural phenomena in the field as follows:
Participatory observation is considered suitable for researching how batik artisans behave and perceive the realities of people's lives in their common, routine, and natural environments. Furthermore, the role of researcher in this research becomes a consideration for researchers to determine ethnography as the research design. In this study, the researcher only acts as observer and participant in society in dealing with attitudes of entrepreneurs and crafters in facing Covid-19 pandemic [15]. Referring to this, the researcher aims to obtain an overview about creative responses made by batik craftsmen in Trusmi. During field observations, researcher often asked questions in formal and informal ways intended to obtain information about realities found spontaneously in the field. From the description of several ethnographic characteristics that have been previously described, ethnography is believed as the most suitable design to answer the research questions.

\section{DISCUSSION}

One of the factors influencing batik business development is a rapid economic growth. This is in line with the development of batik motifs interested by consumers, not only by regional consumers but also global consumers who come from various countries such as America, Japan and European countries [16].

Looking at the batik business as a trading activities in Indonesia, it comes through several changes not only in economic sector but also in socio-culture aspect. One of them is culture of transactions carried out by craftsmen in their business. In line with this statement, Kuncoro states that transaction culture is determined by several factors including production, marketing strategies, and forms of transactions on global market. These factors were clearly identified throughout this study either through interview instruments, field observations, and analysis of existing documents [17]

\section{A. Batik Production Activities in Indonesia}

Related to batik production, one of batik craftsmen (respondent A), stated that before Cirebon batik was known in global market, the craftsmen carried out conventional production. Batik materials in the form of mori and other materials needed are purchased by the craftsmen themselves. Thus, the number of production depend on financial condition of the craftsmen as described below.

Yes, just as it was ... after depositing batik at the shop, some money we earned was used for buying fabrics and other materials. While some of that money were used for household needs such as buying rice.

This culture still lasted popular until 2000. Along with the raise number of craftsmen in Trusmi, business activities in this area were changing, especially in the way of craftsmen carried out batik production. Although, some craftsmen still rely on personal strength (production, selling, buying materials). The conventional buying and selling scheme show in figure 1 bellow. 


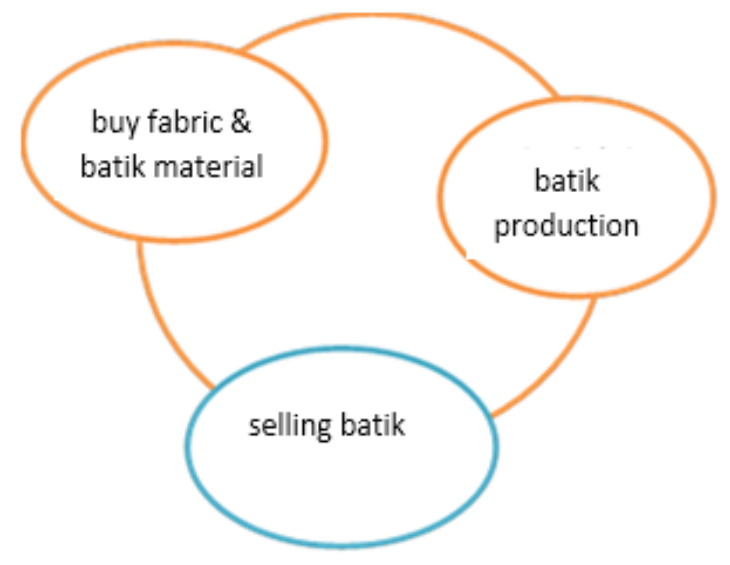

Fig. 1. Conventional buying and selling scheme [16].

Meanwhile, some craftsmen made a breakthrough by sharing responsibility with their customers. The customers provide batik materials and request the motif while the craftsmen just focus on making batik. As said by a craftsman (respondent C);

Now, sometimes I receive materials and motifs from customers. So there is no worries about providing fabric and materials. Batik finished and paid for. Sometimes it's fully paid earlier, or half of it first [18].

In contrast to those two craftsmen's experience, another pattern of batik transaction was done through piece-rate pay system. In this case, the craftsmen only make batik and they are paid per unit of creation with the amount of money that has been agreed first. Many craftsmen are comfortable with this method since they do not bear the production cost. In addition, they are encouraged to produce batik as much as they can. The craftsmen's opinion related to this method can be seen in the following statement:

Since 2012 I have only fulfilled orders from several agencies such as governor office, mayor, the Department of Manpower, etc. they come with materials and motifs... like the way tailors work, the consumers come with fabric and ask to be sewn to fit their desired model [19].

However, this method has both plus and minus points according to craftsmen. In some cases, the craftsmen feel disadvantaged by this method especially when they were paid with lower wages than written in agreement document. Mostly, it happens when they cooperate with government agencies at which the agencies often negotiate prices that are far from the price offered. One of the common reasons for this lower pay is due to absence of trademark provided by the craftsmen. In fact, the craftsmen who do not have a trademark are paid lower than those who have a trademark. It is also one of obstacles faced by the craftsmen where most government agencies prefer to choose craftsmen who already have their own trademark in order to ease administrative report. Therefore, according to craftsman B, he often uses other entrepreneurs' trademarks in order to be accepted administratively by the agencies.
Consequently, he has to share his income with the entrepreneur whose trademark is loaned.

\section{B. Transaction Activities in Cirebon Batik Industry}

Besides production patterns, transaction culture is also being studied in this study. The transaction pattern is referred to economic activity including sale, purchase of goods, and method of payment between the seller and buyer. The findings showed that there are several differences of transaction patterns among craftsmen. First, some craftsmen still use the conventional model which accepts orders from consumers who directly come to the craftsmen's house so that payments are done in cash and carry. According to one of the craftsmen, this method is done until now that he only accepts face to face payment with the customers. In terms of product marketing, he said that there is no specific strategy used to promote his batik products. The customers know his batik quality from recommendation of previous customers. So far, there is no intention from the craftsmen to make his product famously known in wider market. This marketing strategy is also known as word of mouth marketing. According to Buttle, compared to other advertising strategies, it is a more effective advertising strategy to influence costumers in making decisions to buy the products. It is due to marketing perspective which focuses more on interpersonal tactics between buyers and sellers. The advertisements are conveyed through direct, face-to-face, and short interaction which means that marketing process only occurs along with the communication takes place. Unlike advertisements made in print media, word of mouth (WOM) is believed to significantly influence consumers in shopping. However, this type of transaction pattern easily makes sellers in problem if customers are not satisfied with the goods or services [20].

In line with this, Dwiastuti said that consumer behavior is an action, process, and social relationship done by individuals, group, and organizations to obtain and use a product as a result of their experience with other services, products and sources [21]. Therefore, both positive and negative opinions about the product given verbally from other consumers will have a significant impact on consumer behavior. On the other sides, findings in the field also identified that currently some craftsmen start to collaborate with others craftsmen doing on conventional sales. Besides accepting direct orders from customers who comes to their house, craftsman B also markets his products to outlets in Trusmi. By doing so, his product can be easily recognized either by local and foreign customers. Craftman B puts his products to several outlets that become his partners. The craftsman made a deal with the outlets about the price and profit sharing. According to him, there are two kinds of profit sharing namely giving percentage of profit to the partners and determining price at the first. In business, this type of trading strategy is known as a Konsiyasi.

This activity can provide benefits to the craftsmen from several aspects including giving the craftsmen an opportunity to market their products, rather than only passively waiting for orders that directly come to their home. In addition, batik 
craftsmen also do not have to spend cost to rent a place or store for selling their products. In a consignment, the ownership of goods remain at the sender (craftsman), not the party entrusted. Therefore, consigned goods do not belong to inventory of the entrusted party but they are considered as craftsmen's inventory until they are sold to consumers. Unfortunately, this kind of ownership is one of the weaknesses of this transaction technique since the craftsmen will only be paid if their goods are sold. Whereas, the craftsmen have spent money for the production costs. Due to this reason, consignment sale is distinguished from an ordinary sale. In the ordinary sale transaction, all operating costs are borne by seller yet in consignment sales it will be borne to owner of the goods. Consignment sale system can be seen in the following figure 2:

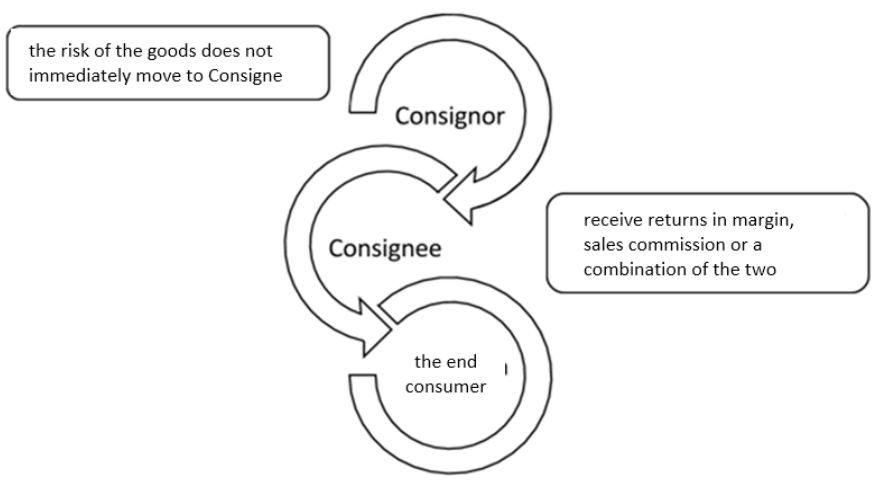

Fig. 2. Sales scheme in the Showroom [16].

It is undeniable that technology development have brought a significant impact on the transaction culture done by Trusmi craftsmen. One of the respondents has implemented the use of online shopping and transfers as parts of their business activities. Craftsman A in his interview explained that the role of technology in transaction style is important. Craftsman A recognized this phenomenon as a means of simplifying transactions, saving time, and reducing marketing costs. Through online system, both entrepreneurs and customers are not limited by time and distance so that transactions can be done anytime. In addition, technology also promotes a safe transaction which can be done through invoicing process of products and services. Through this media, especially sellers can count their sales more practically, easily, and efficiently [17]. Meanwhile, for buyers, the use of technology-based transaction is also urgently needed since it helps them in several things including saving shipping costs, giving convenience, and improving transactions safety, especially for payments. The online transaction can apply several supporting programs such as e-banking, credit card, bank draft and so on. One advantage that is recognized directly by the craftsman is stated in the following statement:

Nowadays everything is easier, as long as we know how to utilize the technology and purpose of transactions. Very fast, cheap, practical, and safe... .. just click click everything is done [22].
Despite using information technology in his transactions, craftsman A also maintains the conventional transaction, namely cash and carry. This is done at several batik shops, galleries, and malls where customers directly make purchases on the shopping spot. However, technological developments have brought batik industry in Trusmi towards modernization. Apart from online sales that have been carried out by some craftsmen, modernization in the Trusmi batik environment is also identified by establishment of Trusmi Batik Modern Market (BT). It is an entertainment spot with one-stopshopping concept consisting of batik supermarkets, clothing, food, dining, ATM centers, and batik studios provided for visitors. The place is visited by both domestic and foreign customers. Batik Trusmi is categorized as a modern market where goods are sold with a fix price so there is no bargaining process. According to Aryanti modern market has effective and efficient conditions in terms of [23]: (1) higher utilization of space, equipment and people; (2) better flow of information, goods, or people; (3) employee with a better behavior as well as a safer working environment; (4) better customer interaction; (5) flexibility. Modern markets usually provide retail layout, while traditional markets are inconsistent in their arrangement products. Thus traditional market seems to be chaotic in its operation.

Various types of transaction found in Trusmi batik business either through traditional and modern way can be indicator that batik business in Trusmi has developed. According to entrepreneurs, the choice of transaction depends on demand of buyers, either local, cross-regional, and international, as highlighted by Kuncoro [17].

\section{FINDINGS}

One of the factors influencing decline in Indonesian batik marketing is condition of global covid-19 pandemic around the world. It was found that there is a declining batik demand from March until now not only demand from regional consumers but also global consumers from various countries such as America, Japan and European countries. Looking at business activities in Cirebon batik, several changes not only in economic sector but also in socio-culture have been identified. One of them is the culture of transactions carried out by craftsmen in their business. According to Kuncoro, transaction culture is determined by several factors including production patterns of craftsmen, marketing strategies, and forms of transactions on the global market [17]. These factors were clearly investigated during research in the field either through interview, field observations, or analysis documents. Batik is not just a legacy of valuable goods that have a high selling value but it is also a cultural symbol through which Indonesia's identity is promoted. Although batik has gained legitimacy, it has already received recognition as Masterpieces of the Oral and Intangible Heritages from UNESCO in 2009. However, this award could not help Indonesian batik craftsmen and entrepreneurs from the influence of Covid-19 pandemic crisis. Data of Departement of Industry and Commerce in 2015 shows that there are 5 main destination countries for national batik exports, namely the 
United States, South Korea, Germany, Japan and France. United States is the country with the highest batik export value achieving USD 81.38 million. In general, the export destination countries for batik are developed countries prioritizing quality of the product. In fact, national batik industry depends on these countries for business sustainability. After demand for batik imports from these countries stopped for several months due to Covid-19 pandemic, the sustainability of Indonesian batik industry collapsed except for batik craftsmen who are members of the small and medium business groups (UMKM). What was the craftsmen's and entrepreneur's attitude facing Covid-19 pandemic, and their efforts to maintain their business? Even though they face many difficulties, batik activities still run during this pandemic. It is recorded that 151,565 batik entrepreneurs in Indonesia who are members of the Indonesian Entrepreneurs and Craftsmen Association have held a Seminar through Zoom which can be attended by all people who are interested in batik world. At the same time, the Webinar was held a Batik Bazaar which is a kind of selling media through internet. This is one of the results from exploring Digital Marketing Handholding innovation. The Association of Indonesian Batik Entrepreneurs and Craftsmen also sells its batik products through Batik Entrepreneurs Community forum named WASTRA or wastra.id. WASTRA accommodates 502 large-sized batik entrepreneurs and 1,279 medium-sized entrepreneurs who are supported by 2,612 Small and Medium Enterprises across Java and Madura Island. Currently, there are several areas that become centers of national batik industry, namely Yogyakarta, Solo, Pekalongan, Cirebon, and others. Each region has its own uniqueness. One of the batik industry centers in Indonesia that is very fast growing is Cirebon batik industry. Batik Cirebon is famous for its Mega Mendung and Wadasan motifs which are in great demand by customers. The small and medium-sized batik industry (IKM) of Cirebon batik has grown rapidly in the last 10 years or so. It can be seen from the increasing number of batik business units in Cirebon district. Before covid-19 pandemic period, data from Cirebon Regency Industry and Trade Office shows that in 2019 there were 530 business units with a total of 4,410 employees.

\section{CONCLUSION}

Indonesian batik is indeed rapidly developing and growing. Nowadays, almost all cities in Indonesia have a batik industry. Besides differences of batik style among craftsmen, some batik centers follow Market demand for coloring and creating motifs. For example, batik craftsmen's works were made based on market demand in Madura, such as Sekarjagat batik motives, Keong Mas, Matahari, Daun Memba (mojo leaves), Fried Stale have many enthusiasts. The large number of batik centers in Indonesia also have some advantages such as connecting batik community, nurturing batik cultural heritage, and giving additional income which becomes an alternative for economic stagnancy during Covid-19 pandemic crisis.

A sluggish demand of Batik has made marketing batik more difficult. As a result, batik sales drastically decline. This phenomenon can be a basic for arranging materials used in enrichment program for craftsmen about shifting conventional marketing into digital marketing models.

Nevertheless, a support and involvement of state-owned enterprises or private companies in marketing batik craftsmen is valuable for Indonesian batik craftsmen community. By doing so, batik craftsmen can recover soon from this global market crisis. The Ministry of Industry and the Indonesian Batik Foundation should work together to provide support, assistance, websites and create Batik Market in line with the 4.0 industrial revolution program. The use of various advanced technologies is able to make national batik world more competitive. "The development of an inventory works into a digital model is considered important to protect the intangible Indonesia cultural heritage. This is very significant to create Indonesia 4.0 in batik industry. Those facts also strengthen pride of Indonesian people in wearing batik. Those are also done to establish a comparative and competitive product in the international market. In fact, Batik needs to be preserved by strengthening branding and protecting Intellectual Property Rights.

\section{ACKNOWLEDGMENT}

Our gratitude goes to:

- Dear Director General of Higher Education and Ministry of Research and Technology who has provided research funding through the Higher Education Leading Applied Research project from 2019, 2020 and 2021

- The Rector of Universitas Pendidikan Indonesia who has granted permission to conduct research in four areas of Cirebon, Pekalongan, Sragen and Surakarta

- Chairman of the Institute for Research and Community Service, Universitas Pendidikan Indonesia

- Research partners from Batik Hilmi and Batik Katura companies in Cirebon, Surya Kusumo Batik Gallery, Pekalongan Batik House, Dwi Andini Batik House, Sragen

- Research Team "Digital Marketing Handholding"

- Titi Srihayati, Irving Gustav Salim, Muhammad Ajrin Salim who always accompanied the research

\section{REFERENCES}

[1] E. Prakoso, Mengamati batik yang terpajang di Rumah Batik Palbatu [Online] Retrieved from: AKURAT.CO, 2020.

[2] E.I. Apăvăloaie, "The impact of the internet on the business environment," Procedia Economics and finance, 15, 2014, pp. 951-958.

[3] P. Kotler and L.K. Kevin, Marketing management 13. New Jersey: Pearson Prentice Hall, Inc, 2012.

[4] P. Kotler and G. Armstrong, Principle of Market-ing, 14th edn. USA: Pearson Edu-cation, 2012

[5] V. Henderson, A. Storeygard and D.N. Weil, "A bright idea for measuring economic growth," American Economic Review, vol. 101, no. 3, 2011, pp. 194-99 
[6] N. E. Coviello, R. Milley and B. Marcolin, "Understanding IT-enabled interactivity in contemporary marketing," Journal of Interactive Marketing, vol. 15, no. 4, pp. 18-33, 2001

[7] Heidrick and Struggles, Corporate Governance Report 2009: Boards in turbulent times, Paris, 2009.

[8] R. Sanjaya dan J. Tarigan, Creative Digital Marketing. Jakarta: PT Elex. Media Komputindo, 2009.

[9] [9] Tjiptono (1996:146)

[10] J. Deighton and M. Sorrell, "The future of interactive marketing," Harvard business review, vol. 74, no. 6, pp. 151-160, 1996

[11] R. Bogdan and S.K. Biklen, Qualitative research for education. Boston, MA: Allyn \& Bacon, 1997.

[12] S. Reeves, J. Peller, J. Goldman and S. Kitto, "Ethnography in qualitative educational research," AMEE Guide No. 80. Medical teacher, vol. 35, no. 8, pp. e1365-e1379, 2013.

[13] J.P. Spradley, The ethnographic interview. Waveland Press, 2016.

[14] M. Angrosino, "Doing ethnographic and observational research," Sage Applied, vol. 98, no. 2, pp. 253-260, 2007.
[15] Reeves, Scott, Ayelet Kuper, and Brian David Hodges, Qualitative research methodologies: ethnography. Bmj 337, 2008.

[16] A. Nursalim, T.R. Rohidi, T. Triyanto, and S. Iswidiarti, "Batik Wadasan Motif, Past And Present," In Proceeding of International Conference on Art, Language, and Culture, 2017, pp. 215-225.

[17] Kuncoro, M. 2007. Ekonomika industri Indonesia: menuju negara industri baru 2030?. Penerbit Andi.

[18] Wawancara dengan perajin A, Mei 2017

[19] Wawancara dengan perajin C, Mei 2017

[20] F. Buttle, "Shopping motives constructionist perspective," Service Industries Journal, vol. 12. No. 3, pp. 349-367, 1992

[21] R. Dwiastuti, A. Shinta and I. Riyanti, Perilaku konsumen. Dipetik February, 20, 2016, 2012.

[22] Wawancara dengan pengusaha A, 4 Juli 2017

[23] T. Aryanti, "Analisis Perilaku Konsumen dalam Pemilihan Tempat Belanja dengan Pendekatan Analytical Hierarchy Process (Studi Kasus pada Masyarakat di KotaDepok),” Jurnal Skripsi Manajemen Universitas Gunadarma, 2011. 